\title{
Proceedings of the Annual Meeting of the Georgia Association of Mathematics Teacher Educators
}

Volume 8

Issue 1 8th Annual Proceedings

Article 1

2014

\section{Proceedings of the Eighth Annual Meeting of the Georgia Association of Mathematics Teacher Educators Introductory Texts}

DOI

10.20429/gamte.2014.080101

Follow this and additional works at: https://digitalcommons.georgiasouthern.edu/gamte-proceedings

Part of the Mathematics Commons, and the Teacher Education and Professional Development Commons

\section{Recommended Citation}

(2014) "Proceedings of the Eighth Annual Meeting of the Georgia Association of Mathematics Teacher Educators Introductory Texts," Proceedings of the Annual Meeting of the Georgia Association of Mathematics Teacher Educators: Vol. 8 : Iss. 1 , Article 1.

DOI: $10.20429 /$ gamte.2014.080101

Available at: https://digitalcommons.georgiasouthern.edu/gamte-proceedings/vol8/iss1/1

This article is brought to you for free and open access by the Journals at Digital Commons@Georgia Southern. It has been accepted for inclusion in Proceedings of the Annual Meeting of the Georgia Association of Mathematics Teacher Educators by an authorized administrator of Digital Commons@Georgia Southern. For more information, please contact digitalcommons@georgiasouthern.edu. 


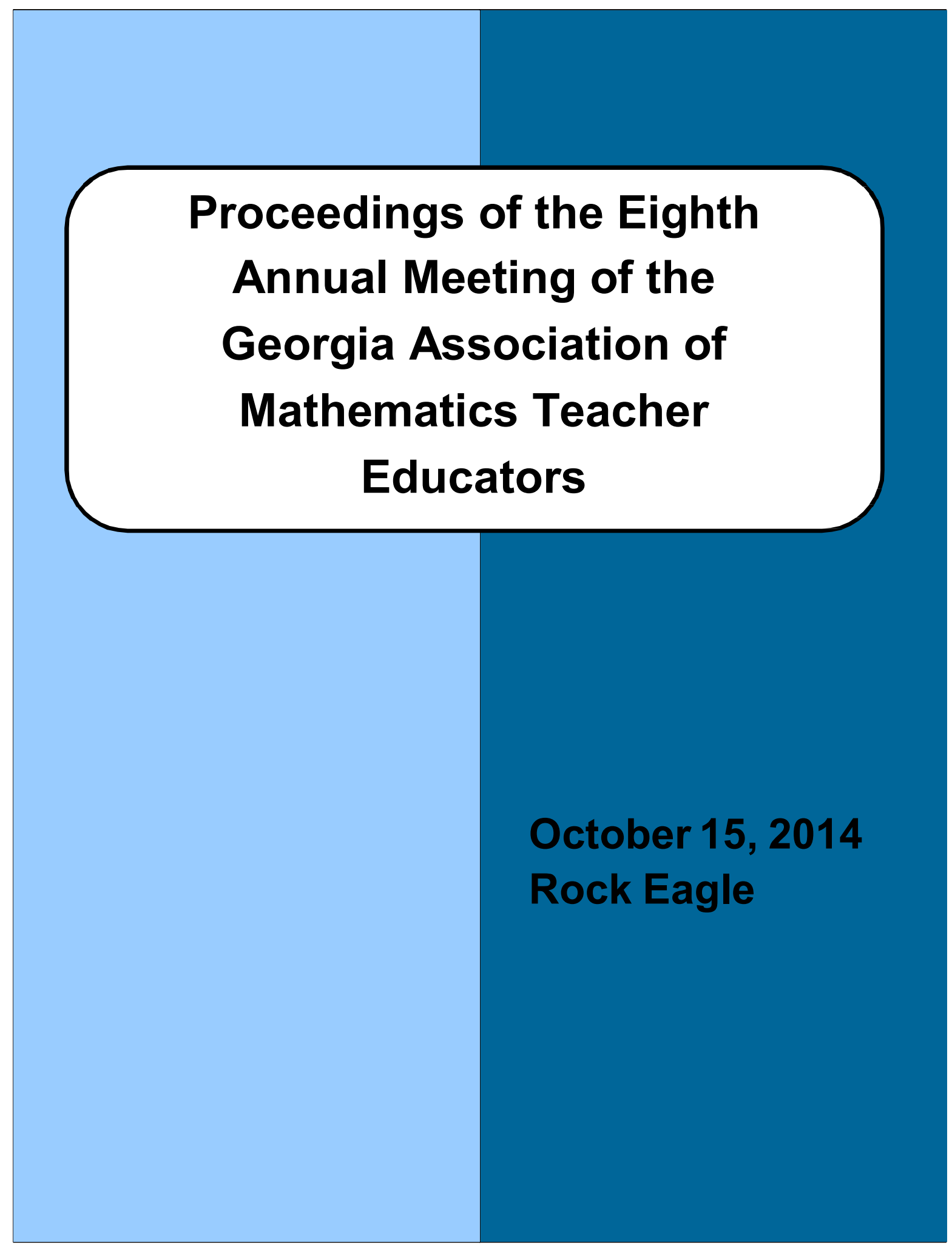




\title{
Georgia Association of Mathematics Teacher Educators (GAMTE)
}

\author{
GAMTE 2014 Officers \\ President: Greg Chambleee, Georgia Southern University \\ President-Elect: Jeffrey S. Hall, Mercer University \\ Secretary: Teresa Banker, University of West Georgia \\ Treasurer: Woong Lim, Kennesaw State University \\ Member-at-Large: Tamara Pearson, Clayton State University \\ Member-at-Large: Angel Abney, Georgia College and State University \\ GAMTE 2014 Conference Committee \\ Gregory Chamblee, Georgia Southern University \\ Jeffrey S. Hall, Mercer University \\ Ha Nguyen, Georgia Southern University \\ Sharon Taylor, Georgia Southern University \\ GAMTE 2014 Proceedings Committee \\ Don K. Brown, Middle Georgia State College \\ Jill Drake, University of West Georgia \\ Jeffrey S. Hall, Mercer University \\ Tamara Pearson, Clayton State University \\ Lynn Stallings, Kennesaw State University \\ Sharon Taylor, Georgia Southern University
}

\section{Purposes and Goals of GAMTE}

The purpose of GAMTE is to encourage and facilitate the improvement of mathematics teacher education across the state of Georgia. The goals of the organization are to: facilitate communication and collaboration among mathematics teacher educators between and within all educational levels; coordinate activities and work collaboratively with other associations, organizations, and governmental (national, state, and local) units to strengthen the mathematical, pedagogical, and clinical preparation of mathematics teachers at all levels (P-college); facilitate collaboration among mathematics teacher educators who are members of different academic units, such as departments of mathematics and departments of education; promote leadership among mathematics teacher educators in the broader mathematics education community; encourage research related to mathematics teacher education, especially which identifies factors that contribute to improving the preparation and professional development of mathematics teachers at all levels; encourage and organize programs and meetings focusing in issues related to the preparation and professional development of mathematics teachers; and foster the incorporation of appropriate technology into teacher education programs and professional development opportunities in mathematics at all levels ( $\mathrm{P}$ - college). 


\section{Letter from the President}

\section{A Letter from the President}

The eighth annual conference of the Georgia Association of Mathematics Teacher Educators provides an opportunity for mathematics educators to meet, discuss and present scholarly works about mathematics teaching and learning. The conference also presents a time for members to discuss 'initiatives' at their institutions and 'catch-up' on mathematics education in Georgia in general. This year's conference presentations are a mix of research and practice sessions. These proceedings represent a sample of the work of the membership over the past year.

The annual conference and proceedings would not be possible without the work of many individuals. Thanks to Conference Co-chairs Sharon Taylor, Ha Nguyen and Gregory Chamblee for putting together a very diverse program. Thanks to Proceedings Co-Editors Jeffrey Hall and Don Brown along with the review committee (Jill Drake, Tamara Pearson, Lynn Stallings and Sharon Taylor) for reviewing submitted papers and preparing each paper for publication. Thanks to all the presenters for disseminating their research and practices to the membership.

Leadership is the key to the sustainability of an organization. We thank Sharon Taylor (PastPresident) for all of her work and Jeffrey Hall (President-Elect) for all of his work during the past year. We look forward to the leadership of Jeffrey Hall (President) and the incoming officers as they continue to move the organization forward.

Mathematics-related issues in Georgia continue to change by the day. I personally want to thank each member for making Georgia Association of Mathematics Teacher Educators a viable voice in this discussion. It has been a pleasure serving as your President for the past two years. Thanks for all you do!

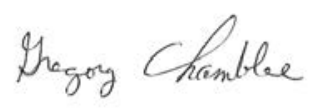

Gregory Chamblee 
A Proposed Pedagogical Approach for Preparing Teacher

Page Number

Candidates .5

to Incorporate (Academic)

Woong Lim, Kennesaw State University

Lynn Stallings, Kennesaw State University

Design Considerations for Visually-Aided Discussion Prompts: Emphasizing

Mathematical Reasoning in Teacher Education

Anne Marie S. Marshall, Berry College

Kadian M. Callahan, Kennesaw State University

Differences in Beliefs Across a Series of Four Mathematics Content Courses

Susanna Molitoris Miller, Kennesaw State University

Caitlin Walkey, Kennesaw State University

Do You See What I See? Deepening Teachers' Understanding of Linear Equation

Through Student Interviews

Tamara Pearson, Clayton State University

Kelli Nipper, Clayton State University

Catherine Matos, Clayton State University

CAEP, NCTM, and Secondary Mathematics Program Revisions

Dianna Spence, University of North Georgia

A Mathematics Teacher's Journey of Identity Construction and Change

Anthony B. Stinson, Clayton State University 